\title{
Factor Stability of the Adam's Perceived Wellness Survey Adam's 個人康盛評價量表的因子穏定性
}

\author{
Lena FUNG Jofy PANG \\ Department of Physical Education, \\ Hong Kong Baptist University, HONG KONG
}

傌蓮娜＼cjkstart彭秀蓮

香港浸會大學體育學系

\begin{abstract}
Composites of wellness have been conceptualized as having six, seven, eight, or more dimensions depending on the theoretical bias of individual scholar. This paper aims to introduce an instrument that can be used to evaluate the six dimensions commonly accepted as the basic essential elements of wellness and to report on the factor stability of the instrument with data collected from a sample of university students studying in Hong Kong. This instrument is the Perceived Wellness Survey developed by Adams and his associates.
\end{abstract}

Key Words: Perceived Wellness Survey, factor stability

\section{摘 要}

現今用以測量個人康盛概況的自評量表頗多, 本文旨在介紹一個精簡而能完整地測量個人康盛概況的量表及其因子的穩定 性。

\section{Introduction}

Wellness has been accorded increased importance by health professionals ever since its conceptualization by Dunn in the early 60s (Lafferty, 1979). Over the years, scholars have grappled with describing what wellness actually incorporates. To date, there is a general consensus that wellness is a state of optimal functioning of an individual in at least six aspects, namely, the physical, emotional, intellectual, spiritual, social, and psychological aspects (Whitmer \& Sweeney, 1992; Depken, 1994; Adam, Bezner, \& Steinhardt, 1997).
Paralleling the agreement of what wellness constitutes, a number of instruments to measure wellness have been developed. However, whereas some are quite lengthy, for example the Five Factor Wellness Inventory (Meyers, Witmer, \& Sweeney, 1996), others, such as the Friedman Well-Being Scale (Friedman, 1992) and the Quality of Well-Being Scale (Kaplan, Sieber, \& Ganiats, 1997), do not capture the range of dimensions commonly accepted by health professionals as essential for a holistic concept of wellness. This paper aims to introduce an instrument that can address both these concerns and reports on the factor stability of the instrument with data collected from a sample of university students studying in Hong Kong. The instrument being evaluated for psychometric properties is the Perceived Wellness Survey (Adams, Bezner, \& Steinhardt, 1997). 


\section{Method}

\section{Participants}

The data set for this paper was a sub-set of data taken from a larger study undertaken by Pang (2010). Pang's study involved students undertaking undergraduate studies in one of the eight universities receiving grants from the University Grants Council (UGC). At the time of her data collection, the respondents were enrolled as full-time students in one of the UCG funded programs leading to a bachelor degree. They were invited to respond to the PWS, presented to them in English, together with several other instruments that Pang had selected for her study.

The analysis for this paper was performed with a data set that had been cleaned for outliers and tested for homogeneity. The data set came from 691 individuals of which 273 were male students and 418 were female students. Their age range was between 18 and 33 ( $\mathrm{M}=$ 21.2, $\mathrm{SD}=1.47$ ).

\section{Instrument}

The instrument being evaluated in this study was the Perceived Wellness Survey (PWS) developed by Adams et al. (1997). The PWS contains 36 items scored on a 6-point scale. The anchors for the points were as follows: 1 = Very strongly disagree, $2=$ Strongly disagree, $3=$ Disagree, $4=$ Agree, $5=$ Strongly agree, and $6=$ Very strongly agree.

The PWS was also designed in such a way that each wellness dimension, containing 6 items, can be represented by the summation of respective sub-score. Hence, the sub-scales of the instrument were named: Intellectual wellness (INT), Psychological wellness (PSY), Social wellness (SOC), Emotional wellness (EMO), Physical wellness (PHY), and Spiritual wellness (SPR). In the initial study, the internal consistency estimates for each sub-scale as reported by Adams et al. (1997) were as follows: $\mathrm{INT}=.64, \mathrm{PSY}=.71, \mathrm{SOC}=.64, \mathrm{EMO}=$ .74 , PHY $=.81$, and SPR $=.77$. Relating to the internal consistency estimate of the total scale, the obtained range from four separate samples in the original study was reported to be from .88 to .93 . In later studies, the internal consistency of the total scale was also found to be high (cf. Benzer, Adams, \& Whistler, 1999; Dolbier, Soderstrom, \& Steinhardt, 2001).
In developing the PWS, Adams et al. (1997) had purposely tried to minimize the item-order effect by placing each item corresponding to each of dimension on a randomly shuffled order in the presentation of the final version of the instrument. Of the 36 items, 15 were negatively stated and 21 were positively stated. The distribution of these negative and positive statements within each of the 6 wellness dimensions was also randomly placed.

\section{Statistical Analysis}

LISREL, version 8.7 was used in assessing the structural model of the PWS as described by Adams et al. (1997). To determine whether the model tested was tenable with respect to the data, a variety of fit indices popularly used for a purpose similar to the present study were adopted for use. These included the Tucker-Lewis Index (Kline, 2005), Goodness of Fit Index (Joreskog \& Sorbom, 1993), Standardized Root Mean Square Residual (Hu \& Bentler, 1999), and the $x^{2} / d f$ (Browne \& Cudeck, 1993). For the former two indices (TLI and the AGFI), the values generally range from 0 to 1.0 , with larger values suggesting a better model fit. For the Standardized Root Mean Square Residual (RMSEA), a cutoff value close to 0.06 signifies a good fit (Hu \& Bentler, 1999) whereas for the $\mathrm{x}^{2} / \mathrm{df}$ value, a value of 3.0 or less is necessary (Kline, 2005).

\section{Results}

\section{Descriptive statistics}

For data entry, all negatively stated items were reversed prior to further analyses. Table 1 is a summary of mean and standard deviation values for the 36 items. To facilitate referencing, all items of the same dimension are grouped together for presentation and the originally negative items are in italics. The correlation matrix of all items is presented in Table 2 . 
Table 1. Mean and standard deviation of the items of the PWS.

\begin{tabular}{|c|c|c|}
\hline Dimensions and corresponding items & Means & $\begin{array}{l}\text { Standard } \\
\text { deviations }\end{array}$ \\
\hline \multicolumn{3}{|l|}{ Intellectual } \\
\hline $\begin{array}{l}6 \text { I will always seek out activities that challenge me to think } \\
\text { and reason. }\end{array}$ & 4.12 & 0.96 \\
\hline 12 I avoid activities which require me to concentrate. & 4.30 & 1.06 \\
\hline $\begin{array}{l}18 \text { Generally, I feel pleased with the amount of intellectual } \\
\text { stimulation I receive in my daily life. }\end{array}$ & 4.12 & 0.82 \\
\hline $\begin{array}{l}24 \text { The amount of information that I process in a typical day is } \\
\text { just about right for me (i.e., not too much and not too little). }\end{array}$ & 3.80 & 0.96 \\
\hline $\begin{array}{l}30 \text { In the past, I have generally found intellectual challenges to be } \\
\text { vital to my overall well-being. }\end{array}$ & 3.98 & 0.93 \\
\hline 36 My life has often seemed void of positive mental stimulation. & 3.62 & 1.05 \\
\hline \multicolumn{3}{|l|}{ Psychological } \\
\hline 1 I am always optimistic about my future. & 4.26 & 1.00 \\
\hline 7 I rarely count on good things happening to me. & 3.67 & 1.22 \\
\hline $\begin{array}{l}13 \text { always look on the bright side of } \\
\text { things. }\end{array}$ & 4.11 & 1.03 \\
\hline 19 In the past, I have expected the best. & 4.02 & 1.08 \\
\hline 25 In the past, I hardly ever expected things to go my way. & 3.76 & 1.06 \\
\hline 31 Things will not work out the way I want them to in the future. & 3.75 & 1.07 \\
\hline \multicolumn{3}{|l|}{ Social } \\
\hline 3 Members of my family come to me for support. & 4.47 & 1.05 \\
\hline $\begin{array}{l}9 \text { Sometimes I wonder if my family will really be there for me } \\
\text { when I am in need. }\end{array}$ & 3.86 & 1.35 \\
\hline $\begin{array}{l}15 \text { My friends know they can always confide in me and ask me } \\
\text { for advice. }\end{array}$ & 4.25 & 0.88 \\
\hline 21 My family has been available to support me in the past. & 4.49 & 1.09 \\
\hline $\begin{array}{l}27 \text { In the past, I have not always had friends with whom I could } \\
\text { share my joys and sorrows. }\end{array}$ & 4.17 & 1.37 \\
\hline 33 My friends will be there for me when I need help. & 4.42 & 1.03 \\
\hline \multicolumn{3}{|l|}{ Emotional } \\
\hline $\begin{array}{l}2 \text { There have been times when I felt inferior to most of the } \\
\text { people I knew. }\end{array}$ & 3.54 & 1.13 \\
\hline 8 In general, I feel confident about my abilities. & 4.19 & 0.93 \\
\hline 14 I sometimes think I am a worthless individual. & 4.13 & 1.24 \\
\hline 20 I am uncertain about my ability to do things well in the future. & 3.47 & 1.13 \\
\hline 26 I will always be secure with who I am. & 3.99 & 1.05 \\
\hline 32 In the past, I have felt sure of myself among strangers. & 3.72 & 1.01 \\
\hline \multicolumn{3}{|l|}{ Physical Ply } \\
\hline 4 My physical health has restricted me in the past. & 4.11 & 1.34 \\
\hline 10 My body seems to resist physical illness very well. & 3.88 & 1.13 \\
\hline 16 My physical health is excellent. & 3.86 & 1.13 \\
\hline $\begin{array}{l}22 \text { Compared to people I know, my past physical health } \\
\text { has been excellent. }\end{array}$ & 3.91 & 1.24 \\
\hline 28 I expect to always be physically healthy. & 4.35 & 1.06 \\
\hline 34 I expect my physical health to get worse. & 3.97 & 1.27 \\
\hline \multicolumn{3}{|l|}{ Spiritual } \\
\hline 5 I believe there is a real purpose for my life. & 4.57 & 0.96 \\
\hline 11 Life does not hold much future promise for me. & 3.73 & 1.13 \\
\hline 17 Sometimes I don't understand what life is all about. & 3.67 & 1.20 \\
\hline $\begin{array}{l}\text { I feel a sense of mission about my } \\
\text { future. }\end{array}$ & 4.23 & 1.04 \\
\hline 29 I have felt in the past that my life was meaningless. & 4.37 & 1.22 \\
\hline 35 It seems that my life has always had purpose. & 4.21 & 1.07 \\
\hline
\end{tabular}

** Italic items are stated in the negative (shown values are reversed) 


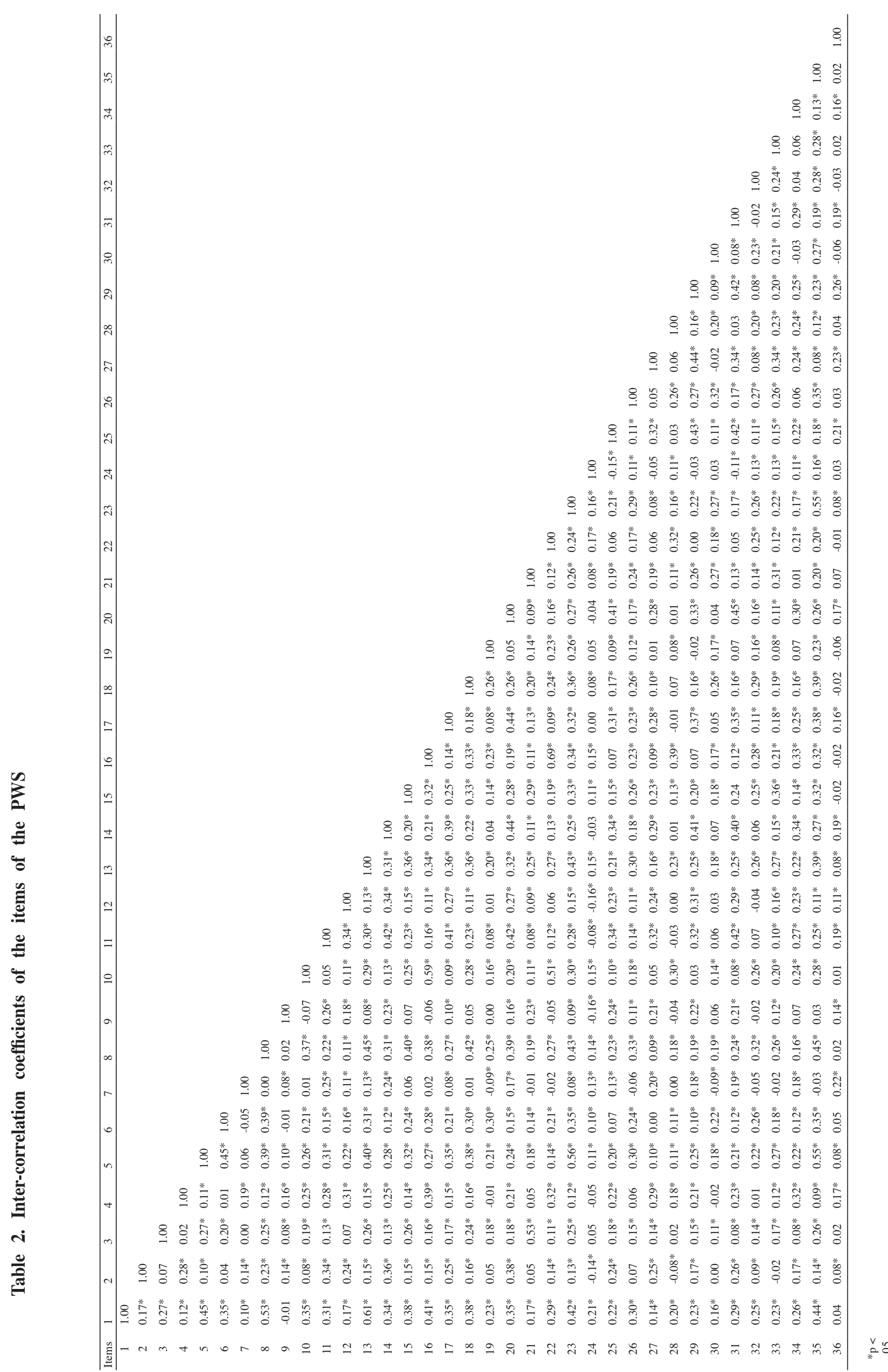




\section{Adam's Factor Structure}

The original factor structure of the PWS as presented by Adams et al. (1997), identified here as Model 1, was subjected to analysis. However, the data set fails to fit the specified model, hence a series of sequential confirmatory factor analyses were conducted with the LISREL 8.7 program so as to re-build the model according to the theoretical construct posited by Adams et al. (1997). This method of beginning from the basics was recommended by Joreskog and Sorbom (1993).

\section{Sequential Confirmatory Factor Analyses}

In performing this series of sequential confirmatory analyses, each dimension of wellness was tested independently such that the data set of items corresponding to each dimension was subjected to confirmatory analysis. The same set of pre-selected fit indices was used to evaluate the tenability of each model. Table 3 contains the identified and contributing items to each dimension together with the fit indices for each model.

Table 3. Standardized item coefficients and model fit indices of the dimensions of the PWS.

\begin{tabular}{|c|c|c|c|c|c|}
\hline Dimension and corresponding items & $\begin{array}{l}\text { Standardized } \\
\text { Coefficients }\end{array}$ & $\begin{array}{l}\text { Tucker Lewis } \\
\text { Index }\end{array}$ & $\begin{array}{l}\text { GFI } \\
\text { Index }\end{array}$ & RMSEA & $x^{2} / d f$ \\
\hline Intellectual & & 1 & 1 & 0 & 0 \\
\hline $\begin{array}{l}\text { 6. I will always seek out activities that challenge me to think and } \\
\text { reason }\end{array}$ & 0.48 & & & & \\
\hline $\begin{array}{l}\text { 18. Generally, I feel pleased with the amount of intellectual } \\
\text { stimulation I receive in my daily life }\end{array}$ & 0.48 & & & & \\
\hline $\begin{array}{l}\text { 30. In the past, I have generally found intellectual challenges to be } \\
\text { vital to my overall well-being }\end{array}$ & 0.41 & & & & \\
\hline \multicolumn{6}{|l|}{ Psychological } \\
\hline 1. I am always optimistic about my future & 0.84 & 1 & 1 & 0 & 0 \\
\hline 13. I always look on the bright side of things & 0.73 & & & & \\
\hline 31. Things will not work out the way I want them to in the future & 0.34 & & & & \\
\hline \multicolumn{6}{|l|}{ Social } \\
\hline 3. Members of my family come to me for support & 0.72 & 1 & 1 & 0 & 0 \\
\hline $\begin{array}{l}\text { 15. My friends know they can always confide in me and ask me for } \\
\text { advice }\end{array}$ & 0.33 & & & & \\
\hline 21. My family has been available to support me in the past & 0.85 & & & & \\
\hline \multicolumn{6}{|l|}{ Emotional } \\
\hline $\begin{array}{l}\text { 2. There have been times when I felt inferior to most of the people } \\
\text { I knew }\end{array}$ & 0.60 & 0.98 & 1 & 0.04 & 2.42 \\
\hline 8. In general, I feel confident about my abilities & 0.47 & & & & \\
\hline 14. I sometimes think I am a worthless individual & 0.77 & & & & \\
\hline 20. I am uncertain about my ability to do things well in the future & 0.81 & & & & \\
\hline \multicolumn{6}{|l|}{ Physical } \\
\hline 4. My physical health has restricted me in the past & 0.42 & 1 & 1 & 0 & 0.52 \\
\hline 10. My body seems to resist physical illness very well & 0.66 & & & & \\
\hline 16. My physical health is excellent & 0.90 & & & & \\
\hline $\begin{array}{l}\text { 22. Compared to people I know, my past physical health has been } \\
\text { excellent }\end{array}$ & 0.77 & & & & \\
\hline 28. I expect always to be physically healthy & 0.43 & & & & \\
\hline \multicolumn{6}{|l|}{ Spiritual } \\
\hline 5. I believe there is a real purpose for my life & 0.74 & 1 & 1 & 0 & 1.55 \\
\hline 17. Sometimes I don't understand what life is all about & 0.47 & & & & \\
\hline 23. I feel a sense of mission about my future & 0.73 & & & & \\
\hline 35. It seems that my life has always had purpose & 0.75 & & & & \\
\hline
\end{tabular}




\section{Confirmed PWS Model}

After obtaining the acceptable model for each dimension, a confirmatory factor analysis was conducted with wellness specified as the higher factor order. During the model fitting procedure, several items were trimmed due to high within-factor and between factors correlated measurement errors. The rationale and cautions related to model trimming has been extensively mentioned elsewhere (for example Kline, 2005) and will not be repeated here. However, it must be noted that the eventual model presented in Figure 1 was trimmed with these concepts in mind and although the final model presented is less complex as compared to the original model proposed by Adams et al. (1997) in terms of the number of items, all the first order and second order factor structures were retained. The accepted model and associated coefficients and fit indices are presented as Figure 1.

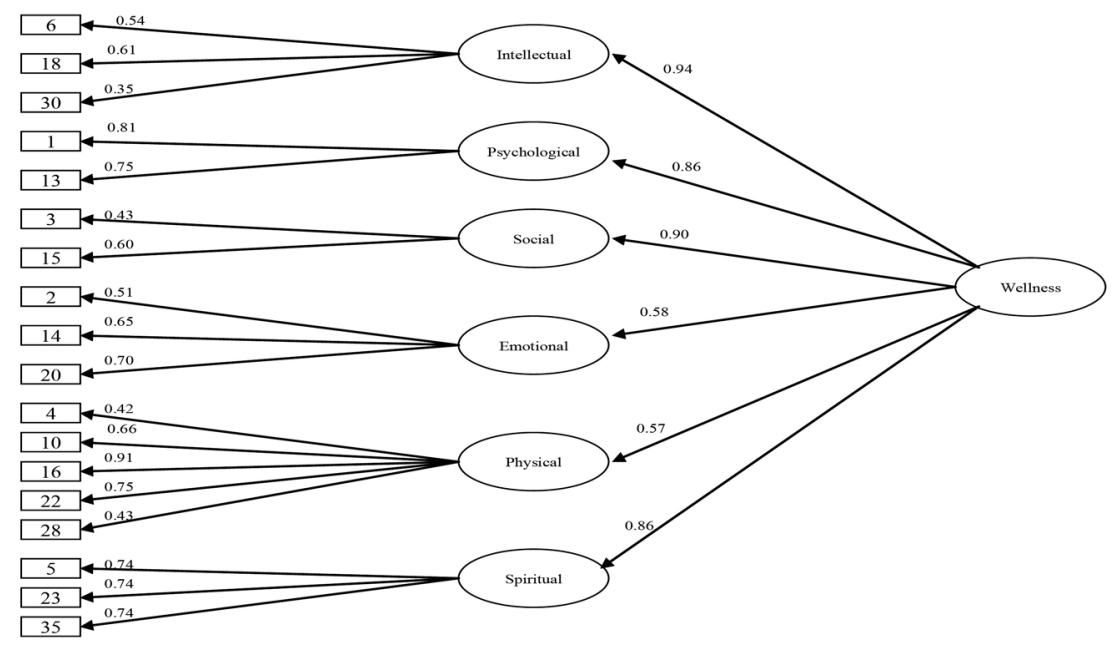

Figure 1: Factorial structure of the PWS with standardized coefficients.

(Fit indices: Tucker-Lewis $=0.97$, GFI $=0.95$, RMSEA $=0.04, \mathrm{x}^{2} / \mathrm{df}=2.64$ )

\section{Conclusion}

Surveys instruments are developed based on strong theoretical concepts. However, in the process of being used in research by different scholars, particularly in different cultural contexts, subjecting the instrument to statistical procedures to evaluate its psychometric properties is desirable and essential (Nunnally \& Bernstein, 1994). The purpose of this paper was to describe one of such attempt.

The PWS was developed with data collected from the United States of America (US) and has been used by scholars working in the US environment. As wellness begins to take root in Hong Kong, the need to validate instruments developed from a culture from where the concept of wellness is originally conceptualized is important. This study embarked on assessing the factor stability of one such instrument that was developed with wellness being viewed as a construct with multidimensions. As this multi-dimensional nature of wellness is concurrently held by many professionals who work in the field of assessing and providing wellness programs, the immediacy of identifying a valid instrument for use in Hong Kong is recognized.

The result of subjecting data of the PWS to confirmatory analysis suggested that the first and higher orders of the PWS are valid. However, by cleaning out some of the items that are non-contributory to the first order factors, an instrument that can measure the same dimensions of wellness emerged. It is recommended that more studies with this short form of the PWS be made so as to consolidate the findings from this study. 


\section{References}

Adams, T.B., Bezner, J.R., \& Steinhardt, M.A. (1997). The conceptualization and measurement of perceived wellness: Integrating balance across and within dimensions, American Journal of Health Promotion, 11, 208-218.

Bezer, J.R., Adams, T.B., \& Whistler, L.S. (1999). The relationship between physical activity and indicators of perceived wellness. American Journal of Health Studies, 15, 130-138.

Browne, M.W., \& Cudeck, R. (1993). Alternative ways of assessing model fit. In K.A.

Bollen \& J.S. Long (Eds.), Testing structural equation models (pp. 136-162). Newbury Park, CA: Sage.

Depken, D. Wellness through the lens of gender: A paradigm shift. Wellness Perspective, 10, 54-69.

Dolbier, C.L., Soderstrom, M., Steinhardt, M.A. (2001). The relationship between self-leadership and enhanced psychological, health, and work outcomes. The Journal of Psychology, 135, 469-485.

Friedman, P.H. (1992). Friedman Well-Being Scale. Retrieved July 31, 2007 from http://www. integrativehelp.com/books_tapes.html

Hu, L.T., \& Bentler, P.M. (1999). Cutoff criteria for fit indexes in covariance matrix analysis: Conventional criteria versus new alternatives. Structural Equation Modeling, 6, 1-55.

Joreskog, K.G., \& Sorbom, D. (1993). LISREL 8 user's reference guide. Chicago, IL: Scientific Software International, Inc.

Kaplan, R.M., Sieber, W.J., \& Ganiats, T.G. (1997). The quality of well-being scale: Comparison of the interviewer-administered version with the selfadministered questionnaire. Psychology and Health, 12, 783-791.

Kline, R.B. (2005). Principles and practice of structural equation modeling $\left(2^{\text {nd }}\right.$ ed.). New York, NY: Guildford Press.
Lafferty, J. (1979). A credo for wellness. Health Education, 10, 10-11.

Meyer, J.E., Witmer, J.M., \& Sweeney, T.J. (1996). The wellness evaluation of lifestyle. Palo Alto, CA: Mind Garden, Inc.

Nunnally, J.C., \& Bernstein, I.H. (1994). Psychometric theory ( $3^{\text {rd }}$ ed.). New York, NY: McGraw-Hill.

Pang, J. (2010). The contributors to academic stress and wellness of university students. Doctoral dissertation under preparation, Hong Kong Baptist University, Hong Kong.

Whitmer, J. \& Sweeney, T. (1992). A holistic model for wellness prevention over the life span. Journal of Counseling and Development, 71, 140-148.

\section{Correspondence:}

Prof Lena Fung

Department of Physical Education, Hong Kong Baptist University,

Kowloon Tong,

Hong Kong.

Email: lenaf@hkbu.edu.hk 